DOI https://doi.org/10.32837/app.v63i0.7

УДК 321:352.07(477)

Мішин C. I. * (HУ «ОЮА»)

\title{
ІСТОРИЧНЕ ПОНЯТТЯ МІСЦЕВОГО САМОВРЯДУВАННЯ
}

\section{THE HISTORICAL CONCEPT OF LOCAL SELF-GOVERNMENT}

*Serhii Mishyn - PhD Student (Political Science), Political Theories Department, National University "Odesa Law Academy"(23, Fontanska Doroha St., Odesa, Ukraine).

\section{Abstract}

The article examines the specifics of forming a national model of local selfgovernment in Ukraine through the lens of history and modernity. The main stages of development and formation of the Ukrainian model of local self-government in the context of foreign experience and domestic scientific practices are revealed. The main guidelines for the transformation of the national model of local selfgovernment in the context of the historical development of Ukrainian statehood are identified. The scientific and practical experience of local self-government research in Ukraine is generalized. It is concluded that the national model of local self-government in Ukraine is still in a state offormation and this process is under the influence of external and internal threats of Ukrainian statehood.

Therefore, summarizing the results of the study, we can draw the following conclusions. First, local self-government in Ukraine was formed much earlier than naturally occurring state power. Local self-government in our country has long been formed vertically with some elements of decentralization (specifics of implementation of the Magdeburg Law in Ukraine). Secondly, the formation of the national model of local self-government has been interrupted for more than 300 years due to the entry of part of the Ukrainian lands into the Russian Empire, the Commonwealth and Austria-Hungary. As a result, Ukrainian lands have heterogeneous experience in forming a national model, where, on the one hand, the territory of our country developed classic European decentralization, and, on the other, the experience of building a rigid vertical system between the "center" and "regions". Third, the Soviet system of local self-government, which was de facto absent, built a principle such as administrative management, where 
the totality of decisions is coordinated and implemented through a system of vertical communications. This system is still in place at the institutional level, which does not allow the transformation of local self-government into the Ukrainian national decentralized model.

Keywords: local self-government, territorial community, Magdeburg law. united territorial community,

Управління в українських містах та регіонах традиційно базувалося на використанні різних історичних форм місцевого самоврядування (вічового права, магдебурзького права, козацького самоврядування, земства тощо), що відповідало загальним тенденціям розвитку європейської цивілізації.

На жаль, поступальний розвиток місцевого самоврядування було зупинено із втратою державної самостійності України в 1920 р. та встановленням централізованої системи територіальної організації влади, яка передбачала пряме державне управління на всіх субнаціональних територіальних рівнях; формально - через єдину систему органів державної влади - Ради народних депутатів, а фактично - через централізовану, підпорядковану по вертикалі систему партійних органів.

Розвал монопартійної командно-адміністративної системи управління, відновлення та розбудова на демократичних засадах української державності об'єктивно привели до пошуку такої організації влади, яка відповідала б як національним традиціям, так і сучасним світовим та європейським демократичним вимогам, була спрямованою на забезпечення прав і свобод людини, задоволення ії потреб, підвищення ефективності надання громадських послуг.

Нова модель влади вже не могла базуватися на політикоорганізаційному принципі “вертикалі влади”, реалізація якого фактично відсторонює людину від участі в управлінні державними та громадськими справами. Світовий і європейський досвід переконливо свідчить, що в демократичному суспільстві територіальна організація влади може будуватися лише на основі обов'язкового використання місцевого самоврядування - специфічної форми публічної влади територіальних громад, у рамках якої забезпечується реалізація їх права здійснювати управління в межах відповідних територіальних одиниць, самостійно вирішувати всі питання місцевого значення.

Історія місцевого самоврядування своїми витоками сягає періоду античності. Ще давньогрецький філософ Арістотель відзначав, що 
в давніх демократіях громадяни управляли саме в тому розумінні, що всі управляли, i, у свою чергу, були керовані. Більше поширення місцеве самоврядування одержало в XI -XV ст., коли в Свропі існували князівства, герцогства, графства, міста, парафії та інші місцеві форми врядування, що з' явилися ще за феодальної доби. Цей процес був пов' язаний з розвитком торгівлі, завдяки чому, у першу чергу, зростали міські громади, багато з яких одержували статус напівсуверенних одиниць, що закладало, таким чином, основу місцевої автономії. У ході розбудови суверенних держав у XVI-XVIII ст. відбувалося підпорядкування міст та інших менших форм місцевих урядувань центральній державній владі. Тому місцева влада почала набувати форми адміністративних підрозділів центрального уряду. Але попередній автономний розвиток міст заклав підгрунтя для існування прав місцевих громад та розвитку їх самоврядування, а процес утвердження домінування центрального уряду, загалом, окреслив роль органів місцевого самоврядування як органів 3 надання місцевих послуг і вирішення місцевих проблем.

Таким чином, історично, під місцевим самоврядуванням розумілось місцеве управління, що самостійно здійснювалось населенням певної територіальної одиниці.

Концептуальні засади теорії та практики місцевого самоврядування були закладені вченими і політиками в період буржуазно-демократичних революцій. Самоврядування пов'язували 3 прогресивними ідеями виборчого права та представницької станової влади в управлінні громадськими справами. Ці ідеї, як відомо, були своєрідною противагою принципам тогочасного середньовічного абсолютизму.

Сам термін “самоврядування" вперше було вжито в період Великої французької революції, щоб підкреслити самостійність громади відносно держави. У 1808 р. міністр Прусії барон фон Штейн використав ідею самоврядування в законі про статути міст, який визначав міську громаду як політичну одиницю. Провідною ідеєю Штейна була організація міської громади в дусі суспільної самостійності, через яку громадянин мав відчути себе членом державного організму (Штейн, 1874, с. 7-8). Цей закон мав велике значення для відродження пруської держави.

Місцеве самоврядування, у його сучасному розумінні, з'явилося в середині XIX ст. Термін “місцеве самоврядування" був введений пруським юристом Р. Гнейстом для такого управління на місцях, при 
якому територіальні громади, що історично склалися, наділялися правом самостійно (у межах законів) вирішувати місцеві справи. При цьому в діяльність громад не втручалась центральна державна адміністрація та ії чиновники на місцях (Панейко, 1963, с. 67-69).

Місцеве самоврядування - це поняття багатозначне, тому в концепціях різних авторів мають місце різні його інтерпретації. Так, відомий німецький правознавець Г. Єллінек ототожнював самоврядування 3 державним управлінням за допомогою осіб, які не $\epsilon$ професійними державними посадовими особами, тобто вважав його управлінням, яке на противагу державно-бюрократичному, є управлінням саме зацікавлених осіб (Еллинек, 1908, с. 470-471). На відміну від нього, англійські вчені І. Редліх і П. Ашлей пов'язували місцеве самоврядування зі здійсненням місцевими жителями або їхніми обраними представниками тих обов'язків і повноважень, що їм надані законодавчою владою або які належать їм за загальним правом (Ашлей, 1910, с. 203).

Інакше формулювали поняття місцевого самоврядування і російські юристи. Так, М. Лазаревський розумів під самоврядуванням вид місцевого державного керування, де самостійність місцевих органів забезпечена такою системою юридичних гарантій, що, створюючи дійсність децентралізації, водночас забезпечується тісний зв'язок органів місцевого самоврядування з даною місцевістю і населенням. Самоврядування розумілося також як самостійне здійснення соціальними групами завдань внутрішнього державного керування в межах об'єктивного права, де гарантією самостійності є створення керівного центру виборним шляхом і автономність діяльності органів самоврядування як форма здійснення державних функцій за допомогою незалежних (тою чи іншою мірою) осіб і об'єднань, а також як перенесення начал представництва і відповідальності на місцеве самоврядування (Черник, 1996, с. 12-17).

Вітчизняні теоретики розглядали місцеве самоврядування через традиційну для українського сільського населення територіальновиробничу форму організації суспільства - громаду. Так, М. Драгоманов вбачав у самоврядуванні оптимальний спосіб подолання надмірної централізації державної влади через широке втілення суспільної свободи на рівні низових адміністративно-територіальних структур, а М. Грушевський розглядав амоврядування як спосіб зміцнення і саморозвитку національних територій ляхом втілення ідей “широкої козацької автономії” (Грушевський, 1991, с. 203-204). 
У період Радянської влади поняття місцевого самоврядування трактувалося інакше. Для його пояснення використовували тези В. Леніна, котрий указував на необхідність залучення всіх громадян до безпосереднього і щоденного управління державою, ув'язуючи з ідеєю відмирання останньої, тобто керування суспільством за допомогою самого суспільства.

Крах тоталітарних режимів у 80-90-ті pp. XX ст. у колишніх соціалістичних країнах, осмислення змін, які сталися у сфері політичної влади і керування, привели до розробки нових підходів у визначенні поняття “місцеве самоврядування". Так, у сучасній науковій літературі України існують різноманітні погляди на визначення понять “місцеве управління" та їхні взаємовідносини. Наприклад, український енциклопедичний словник визначає місцеве самоврядування як одну з форм державного управління на місцях, управління міськими правами, яке здійснюється в обумовленому державою обсязі муніципалітетами, магістратами та іншими органами, що обираються населенням відповідних адміністративних одиниць. Проте важко погодитись $з$ таким визначенням через його державницький аспект.

Але в літературі існують інші погляди, виділяється управлінський аспект місцевого самоврядування, підкреслюється, що це здійснення влади населенням, розглядається місцеве самоврядування як основа онституційного ладу, як форма народовладдя. Треба відзначити, що такі погляди на місцеве самоврядування не викликають сумніву, є сучасними і можуть бути застосовані в конституційній практиці України.

Зрештою, відповідно до Конституції України, місцеве самоврядування - це “право територіальної громади - жителів села чи добровільного об'єднання в сільську громаду жителів кількох сіл, селищ чи міста - самостійно вирішувати питання місцевого значення в межах Конституції і законів України" (ст. 140) (Конституція України: Прийнята на п'ятої сесії Верховної Ради України 28 червня 1996 р.).

Що стосується співвідношення понять "місцеве самоврядування", “місцеве управління", то тут також немає єдиної точки зору.

У роботах окремих дослідників з країн континентального (європейського) права акцентовано на самоврядних засадах в місцевому правлінні як прояві певних “природних" прав, що властиві місцевим громадам. Проте існують твердження щодо “існування муніципальних інститутів як самоврядних органів зовсім не є питанням “природного права", а являє собою результат розвитку політичного процесу". 
У роботах французьких дослідників усе ще спостерігається різниця між "штучно" (тобто актами центральної влади) створеними адміністративно-територіальними одиницями (наприклад кантон, округ) та “природно" складеними формуваннями, які тільки визнані центральною владою (наприклад місто). Вважається, що в керівництві першими мають домінувати інтереси держави, у той час, як інші можуть володіти значними самостійними правами та керуватися, передусім, місцевими інтересами.

Аналіз різних точок зору дозволяє зробити висновок про деяку дуалістичність позицій місцевого управління в межах державного механізму. 3 одного боку, місцеве управління є частиною єдиної публічної адміністрації, децентралізованим та організаційно відокремленим елементом державного механізму, що залежить від центру та виступає як адміністративна організація з надання послуг населенню відповідно до загальнонаціональних стандартів та загального політичного курсу Уряду. На відміну від суб'єктів федерації, автономія місцевих громад має не конституційний, не законодавчий, а лише адміністративний характер. Місцеві органи не мають так званої “компетенції встановлювати свою компетенцію”, тобто не можуть самостійно визначити коло своїх повноважень, оскільки останні встановлюються вищими органами. 3 іншого боку, місцеві органи мають свою власну легітимність, тому що формуються безпосередньо населенням, або за участю населення. Крім того, вони до певної міри самостійні, оскільки мають власні фінансові (податки, що збираються на користь місцевих громад, позики, інші грошові надходження), матеріальні (муніципальна власність) та людські (штат службовців) ресурси, а також юридичні повноваження (наприклад, можливість діяти як юридична особа, укладати договори та порушувати позови).

Отже, місцеве управління, з одного боку, залежить від центральної влади і є своєрідним продовженням державної адміністративної машини на рівень нижчий від центральної, а з іншого - є легітимним виразником ідей місцевих громад.

Місцеве управління відбиває локальні інтереси та самостійну роль місцевих громад у більш широкому державному цілому. Водночас, воно підпорядковане контролю з боку центральної влади і зобов' язане брати участь у реалізації урядової політики на місцях. Місцеве управління, таким чином, може одночасно бути як інструментом центрального контролю за місцевими громадами, так і 
противагою цьому контролю, засобом як подолання місцевого партикуляризму, так і його вираженням.

Вітчизняні дослідники, оперуючи цими термінами, вкладають у них інколи зовсім різний зміст. Наприклад, М. Корнієнко намагається розвести зазначені поняття, позначивши ними дві різні системи, що паралельно функціонують на місцевому рівні. Таким чином, під місцевим управлінням вони розуміють органи, які призначені з центру і представляють державну адміністрацію на місцях, а під місцевим самоврядуванням - місцеві представницькі органи (Корнієнко, 1995).

Частина вчених пропонує розглядати терміни “місцеве самоврядування" та "місцеве управління" як синоніми, оскільки перше, на їх думку, зі складовою частиною другого, уособлюють його суть. Водночас, вони вважають, що "місцеве самоврядування" має своє особливе за змістом навантаження, яке відбиває, передусім, функціональний аспект демократичного управління на місцях, автономію місцевих колективів у межах більш широкого цілого, їх спроможність самостійно вирішувати місцеві проблеми.

Разом з тим, у Конституції України простежується інший підхід, який базується на розрізненні державної влади та влади місцевого самоврядування, у рамках якого місцеве самоврядування неначе виводиться за межі державного механізму.

Але більш слушним видається не протиставлення місцевого самоврядування місцевому управлінню, а розгляд їх у контексті діалектики співвідношення інтересів частин (територій, місць) та цілого (держави).

Особливо цей підхід є актуальним для посттоталітарних країн (зокрема України), коли сама структура цілого, тобто держави, ще формується, вона не склалася остаточно та їй загрожують різні небезпеки. Проте в перспективі демократичного розвитку принцип пріоритетності інтересів, очевидно, має поступатися принципові балансу та гармонізації інтересів центру і територій, держави та ії регіонів. Реальною підставою для зняття суперечностей між центром і місцями, цілими і окремими його частинами, є чітко усвідомлена на політичному рівні і врегульована на законодавчому сфера інтересів і, відповідно, компетенцій між першим і другим.

Такий підхід проголошує і Європейська хартія місцевого самоврядування, прийнята у 1985 р. Радою Європи. В основу цього документа покладено класичний принцип субсидіарності, згідно з яким питан- 
ня, які можна вирішувати на низових рівнях правління, немає потреби передавати вище. Місцевим громадам потрібно довіряти якомога більше управлінських завдань, а втручання держави потрібно лише там, де воно необхідне. Звідси, в Європейській хартії під місцевим самоврядуванням розуміється: “...право і реальна здатність органів місцевого самоврядування регламентувати значну частину місцевих справ і управляти нею, діючи в межах закону, під свою відповідальність і в інтересах місцевого самоврядування". Таким чином, держава повинна створити належну правову базу, а також відповідний політичний клімат, коли органи місцевого самоврядування одержать необхідну їм повноту влади, а також здатність ії здійснювати.

Діалектика інтересів цілого і частини, якщо ії розглядати через призму розподілу влади між державою й органами місцевого самоврядування, повинна враховувати не просто пріоритет цілого над іiі частинами, а й баланс інтересів, мети і цілей, які досягаються шляхом реформування економічних відносин, прав власності, податкових відрахувань та інших платежів, за допомогою яких територіальні суб'єкти перебувають на достатньому рівні самозабезпечення, а держава не втручається в господарсько-фінансовий процес цих суб'єктів. Механізм реалізації концепції балансу інтересів здійснюється через політичну діяльність центру, який надає своїм територіям більше самостійності, та законодавчу практику парламенту, який створює правовий фундамент відносин між владними структурами центру і регіонів, державних адміністрацій і органів місцевого самоврядування.

Ратифікація Україною Європейської хартії місцевого самоврядування виступила своєрідним каталізатором процесів відродження системи представницької влади. Імплементація положень Європейської хартії місцевого самоврядування зумовлює формування якісно нового місцевого самоврядування як системного суспільного явища.

Українська держава докладає значних зусиль у сприянні його становленню, функціонуванню та розвитку. Водночас на думку науковців, політиків, експертів, вітчизняне місцеве самоврядування не виконує насамперед своєї суспільної місії - децентралізації державного управління, організації життєдіяльності на місцевому рівні, формування демократичних основ суспільного розвитку, що ставить під сумнів правильність обраних основ його організації.

Слід наголосити на важливості проведення системних реформ місцевого самоврядування, що удосконалить організацію його 
діяльності шляхом децентралізації державної влади та деконцентрації іiі владних повноважень. Зміцнення організаційної, матеріальнофінансової та правової самостійності представницьких органів місцевого самоврядування має стати передумовою ефективності місцевого управління в регіонах. $Є$ потреба в ретельному дослідженні суперечностей впливу місцевого самоврядування на розвиток громад, стратегічних аспектів діяльності органів місцевого самоврядування, самого процесу реалізації регіональної тратегії розвитку, напрямів формування стратегії регіонів і в розробці методологічного підходу щодо визначення ефективної моделі організації місцевого самоврядування.

В умовах сучасного державотворення України процес пострадянської трансформаційної еволюції представницьких органів місцевого самоврядування потребує об'єктивного аналізу й осмислення соціальних, економічних, культурних, історичних та інших джерел побудови ефективної системи місцевого самоврядування, його трансформаційних процесів в контексті зарубіжного досвіду в єдності з процесами розбудови системи державного управління.

Українське місцеве самоврядування як одна з найдавніших державницьких традицій пройшло досить складний історичний шлях. Його проблеми та взаємовідносини з різними рівнями управління державою були різними на всіх етапах історії України. Особливо загострювалось це питання в короткі проміжки здобуття державності. У такі періоди поставала проблема політичного устрою держави, що вимагала визначення місця й ролі місцевого самоврядування, а також значною мірою впливали східна та західна політичні культури як об'єктивний прояв геополітичного становища нашої країни.

Становлення та розвиток місцевого самоврядування в Україні потребує вирішення широкого кола питань, пов' язаних з будівництвом демократичної держави з ринковою економікою, розвинутою системою соціальних стандартів і гарантій для кожного ії громадянина незалежно від місця проживання.

Важлива роль у демократичній державі належить місцевому самоврядуванню - головному елементу саморегуляції та самоуправління громадян. Місцеве самоврядування сприяє усуненню певної відчуженості населення від влади, є одним з механізмів, здатним підвищити ефективність управління на всіх рівнях.

Впровадження основ місцевого самоврядування потребує подальшого правового регулювання діяльності міських та сільських 
територіальних громад, їх рад, виконавчих комітетів, а також інформаційного забезпечення розвитку місцевого самоврядування.

Об'єднання територіальних громад на сьогодні є однією 3 найбільш обговорюваних тем та напрямів реформ, зокрема, реформи місцевого самоврядування, успішна реалізація якої має стати підгрунтям для створення дійсно спроможних територіаль них громад. Метою реформи місцевого самоврядування є, передусім, забезпечення його спроможності самостійно, за рахунок власних ресурсів, вирішувати питання місцевого значення. Йдеться про наділення територіальних громад більшими ресурсами та про мобілізацію їхніх внутрішніх резервів.

Кожна реформа потребує своїх виконавців та їх глибокого розуміння суті реформування. Без цього будь-яка, навіть найліпше підготовлена, реформа приречена на провал.

\section{Висновки}

За період існування незалежної України місцеве самоврядування поки ще не стало реальною невід'ємною складовою публічної влади. Боротьба гілок влади за перерозподіл владних повноважень перманентно віддзеркалювалася на регіональному рівні та відсувала на другий план основне питання державотворення демократичну організацію місцевої публічної влади, що, у свою чергу, актуалізує вирішення проблеми інституалізації місцевого самоврядування.

Ключовою передумовою зміцнення Української держави, подальшого розвитку громадянського суспільства є глибока і системна реформа місцевого самоврядування. В контексті суспільних, державно-управлінських перетворень в Україні актуалізується питання змін у моделі місцевої влади. Інституційний розвиток місцевого самоврядування з метою нормативно-правового та організаційного забезпечення реформування, а також координування дій органів виконавчої влади та місцевого самоврядування в питаннях реалізації заходів щодо реформи системи місцевого самоврядування, розширення повноважень влади на місцях, зміцнення матеріальнофінансової бази, забезпечення виконавчими функціями - завдання найближчої перспективи.

Вивчення історичних особливостей його розвитку допоможе врахувати помилки й здобутки наших предків, які прагнули збудувати справжню і міцну державу при створенні ефективної місцевої влади, схожої на ті, які вже століттями мають інші нації світу. 


\section{Лimepamypa:}

Ашлей П. (1910). Местное и цуентральное управление. Сравнительный обзор учреждений Англии, Франции, Пруссии и Соединенных Штатов. Спб. XII.

Грицяк I. А. (1995). Періодизація місцевого самоврядування України. Місиеве та регіональне самоврядування України, Вип. 3, № 4 (12-13), 85-97.

Грушевський М. С. (1991). Очерк історії украӥнського народу. К.: Либідь.

Еллинек Г. (1908). Общее учение о государстве. 2-е изд., испр. и доп. по 2-му нем. изд. С. И. Гессеном. Спб.

Конституція України: Прийнята на п'ятої сесії Верховної Ради України 28 червня 1996 р. (1996). К.: Просвіта.

Корнієнко М. I. (1995). Державна влада і місцеве самоврядування: актуальні питання теорії і практики. Українське право, 1 (2), 68-77.

Кравченко В. (1995). Територіальний устрій та місиеві органи влади України. К.: Нац. ін-т стратегічних досліджень, Вип. 43.

Левицька Г., Стецюк П. (1992). До питання про періодизацію розвитку місиевого самоврядування і розвитокмісиевого самоврядування в суверенній Українській правовіӣ державі. Львів.

Панейко Ю.(1963). Теоретичні основи самоврядування. Мюнхен.

Черник И. Д. (1996). Основные теории местного самоуправления: происхождение и развитие. М.: РАН ИНИОН.

Штейн Л. (1874). Учение об управлении и право управления со сравнением литературы и законодательств Франции, Англии, Германии. Спб. XIV.

\section{References:}

Ashley P. (1910). Mestnoye i tsentralnoye upravleniye. Sravnitelnyy obzor uchrezhdeniy Anglii. Frantsii. Prussii i Soyedinennykh Shtatov [Local and central government. A comparative survey of institutions in England, France, Prussia, and the United Sta]. Spb. XII. [in Russian].

Chernik I. D. (1996). Osnovnyye teorii mestnogo samoupravleniya: proiskhozhdeniye i razvitiye [Basic theories of local government: origin and development]. M.: RAN INION. [in Russian]. 
Ellinek G. (1908). Obshcheye ucheniye o gosudarstve [General doctrine of the state]. 2-e izd.. ispr. i dop. po 2-mu nem. izd. SI. Gessenom. Spb. [in Russian].

Grushevs`ky`j M. S. (1991). Ocherk istoriyi ukrayins kogo narodu [An outline of the history of the Ukrainian people]. K.: Ly`bid`. [in Ukrainian].

Gry`cyak I. A. (1995). Periody`zaciya miscevogo samovryaduvannya Ukrayiny` [Periodization of local self-government of Ukraine]. Misceve ta regional ne samovryaduvannya Ukrayiny' [Local and Regional SelfGovernment of Ukraine], Vy`p. 3, \# 4 (12-13), 85-97. [in Ukrainian].

Konsty tuciya Ukrayiny: Pry `nyata na p'yatoyi sesiyi Verxovnoyi Rady Ukrayiny 28 chervnya 1996 r. (1996) [Constitution of Ukraine: Adopted at the Fifth Session of the Verkhovna Rada of Ukraine on June 28, 1996]. K.: Prosvita. [in Ukrainian].

Korniyenko M. I. (1995). Derzhavna vlada i misceve samovryaduvannya: aktual`ni py`tannya teoriyi i prakty`ky` [State power and local selfgovernment: current issues of theory and practice]. Ukrayins `ke pravo [Ukrainian Law], 1 (2), 68-77. [in Ukrainian].

Kravchenko V. (1995). Tery torial 'ny ’j ustrij ta miscevi organy vlady Ukrayiny [Territorial structure and local authorities of Ukraine]. K.: Nacz. in-t strategichny`x doslidzhen`, Vy`p. 43. [in Ukrainian].

Levy`cz`ka G., Stecyuk P. (1992). Do py tannya pro periody zaciyu rozvy'tku miscevogo samovryaduvannya i rozvy tok miscevogo samovryaduvannya $v$ suverennij Ukrayins kij pravovij derzhavi [On the periodization of the development of local self-government and the development of local selfgovernment in a sovereign Ukrainian rule of law]. L'viv. [in Ukrainian].

Panejko Yu.(1963). Teorety chni osnovy`samovryaduvannya [Theoretical bases of self-government]. Myunxen. [in Ukrainian].

Shteyn L. (1874). Ucheniye ob upravlenii i pravo upravleniya so sravneniyem literatury $i$ zakonodatelsto Frantsii. Anglii. Germanii [The doctrine of management and the right of management with a comparison of the literature and legislation of France, England, Germany]. Spb. XIV. [in Russian].

\section{Анотація \\ Мішин С. І. Історичне поняття місцевого самоврядуъання. - Стаття. \\ У статті досліджена специфіка формування національної моделі місце- вого самоврядування в Україні крізь призму історії та сучасності. Виявлено}


основні етапи розвитку та формування украӥнської моделі місиевого самоврядування в контексті зарубіжного досвіду та вітчизняних наукових практик. Визначено головні орієнтири трансформації національної моделі місиевого самоврядування в контексті історичного розвитку української державності. Узагальнено науково-практичний досвід дослідження місиевого самоврядування в Україні. Зроблено висновок, що національна модель місиевого самоврядування в Україні ще перебуває у стані свого формування і цееи процес відбувається під впливом зовнішніх і внутрішніх загроз української державності.

Ключові слова: місиеве самоврядування, територіальна община, Магдебурзке право. об'єднана територіальна громада, 